\title{
Inna hinada hi filet cind erred Ulad inso - Burial and the status of the head*
}

\begin{abstract}
Zusammenfassung
Dieser Aufsatz befasst sich mit dem fragmentarischen Gedicht Inna hinada hi filet cind erred Ulad inso, das sich am Schluss der irischen Handschrift Lebor na hUidre findet. Das Gedicht berichtet laut Überschrift von den Orten, an denen die Köpfe der Helden der Ulaid begraben sind. Zwei Personen, Conchobar mac Nessa und Blaí Briugu, werden in den fragmentarischen Zeilen erwähnt, aber in der überlieferten mittelalterlichen Literatur wird keiner dieser beiden geköpft. In diesem Aufsatz werden daher die möglichen Gründe dafür, dass das Gedicht speziell die Begräbnissorte der Köpfe in den Blick nimmt, untersucht.
\end{abstract}

The last text in the medieval Irish manuscript Lebor na hUidre is a fragmentary poem headed Inna hinada hi filet cind erred Ulad inso ('These are the places in which the heads of the champions of the Ulaid are'), of which only three stanzas survive. Unsurprisingly, given that this appears to be the only copy of the poem, the text has received hardly any attention. ${ }^{1}$ I would like to suggest here that it is influenced by ideas concerning the head's status within the body and, relating to this, ideas connected to burial. In addressing the subject of burial, the poem fits into what is a wider concern in early medieval Irish literature, namely the location of the burial places of secular figures.

\section{The text}

The extant text of the poem, as already stated, consists of three stanzas. It fills the last section of the second column of the page, the rest of the text has not survived due to the loss of the remainder of the pages of the manuscript. Furthermore, letters have been lost in the right-hand side of the column where the

\footnotetext{
* I would like to thank Anna Bredthauer, Barry Lewis and Anna Pagé for their help in checking references to which I did not have access. Furthermore, I am grateful to Máire Ní Mhaonaigh and Elliott Lash for comments on a draft of this article. Jürgen Uhlich and an anonymous reviewer made numerous helpful corrections and suggestions, in particular with regard to textual problems in the poem, for which I would like to express my thanks.

${ }^{1}$ Kuno Meyer (1906: 43-4) notes its existence and gives the text in the notes on Aided Cheltchair maic Uthechair, stating that 'the poem is evidently very old'. His decisions regarding individual readings result in a text that differs slightly from that in Best and Bergin's $L U$ edition (see below).
} 
page has been cut. ${ }^{2}$ Following the heading, the words 'A lLibu[r]' (LU 11053), with the page having been cut after the first stroke of the $u$, would appear to indicate Lebor na hUidre's source for the poem. The text below mainly follows Best and Bergin's diplomatic edition of Lebor na hUidre $(L U)$ and MEYER's text in the notes on Death-tales (1906: 44), with one exception printed in bold. Footnotes indicate where Best and Bergin, on the one hand, and Meyer, on the other, differ, with an explanation of the choice made here. Square brackets indicate where letters have been lost, and text within those brackets represents Best and Bergin's suggested reconstructions, placed in the footnotes in their edition: ${ }^{3}$

Hond úair dundánic Fáilbe
Delíu iar n-imram chu[rach]
indid damse cit n-armand
hi fil chend erred Ul[ad]
Iarna thabairt do Maig" Breg
do Raith Emnae tuaith A[chi?]
adradnacht cend Conchobuir
fora cholaind i mMachi.
Góeta di ág mná Celtchair
cinid cech ind ${ }^{5}$ ha hisil.
cend Blai Briugad iar n-insu
danéim hEmuin fades[in?] $]^{6}$.

1a 'HOND' is printed entirely in capitals in $L U$ (with a further enlarged initial $H$-); for -ond, however, this is not borne out by the manuscript.

1b The text in $L U$ reads 'd'Elíu' and that in Death-tales is 'd'Eliu'. I have not been able to identify a place or person of that name. 'Delíu', on the other hand, a reading suggested to me by the anonymous reviewer, may be interpreted as

${ }^{2} L U$, p. 338, n. 1.

${ }^{3}$ See $L U$, p. 338, notes 2-5. Meyer (1906: 43-4) also suggests reading churach and Ulad in $1 \mathrm{~b}$ and $1 \mathrm{~d}$, respectively, but makes no suggestions for the readings in $2 \mathrm{~b}$ and $3 \mathrm{~d}$.

4 The $g$ of maig appears to have a mark above it, but it does not appear to indicate lenition as this would not comply with the practice of the medieval scribes of the manuscript.

5 Although Best and Bergin's, as well as Meyer's, text originally read 'cechind', the corrigenda to Best and Bergin's reprint include changing 'cechind' to 'cech ind' (see p. 341); the same change is made in the notes added by Bergin to the 1937 reprint of Death-tales, taken from Meyer's copy of the original 1906 edition. The line is very unclear, but as far as it is possible to tell, cech ind makes more sense (see discussion below, p. 73) and has been adopted here.

${ }^{6}$ A mark above the final $s$ may be the beginning of what was a nasal suspension stroke, supporting the suggested final $n$ (cf. $L U$, p. 338, n. 5). 
a dative of the placename found in the genitive Delenn in Chronicon Scotorum (Hogan 1910, s.v. Delenn). There are, however, problems associated with this reading; see the discussion below, $n$. 21 . The length-mark on the final syllable is omitted by Meyer; in the manuscript it spans both $i$ and $u$, and I follow the reading in $L U$

1c Best and Bergin read 'cit n-armand', whereas Meyer reads 'citn' armand'. In both cases, the reading is unusual. Meyer's reading implies citné, 'who, what (is it) that they are?' (see GOI §456, where Thurneysen suggests *cía ata $n$-é as the origin of the phrase), with the final -é elided. This is unparalleled for this phrase and would have to be considered an example of what Jürgen Uhlich has termed 'non-metrical' prevocalic elision (UHLich 2006: 43, n. 63), assuming that the -é of citné could become secondarily destressed before the closely connected stressed word following it (cf. the variant spelling citni cited in DIL s.v. 1 cía A II (q)). Most examples cited by Uhlich are Middle Irish in date. By contrast, the nasalisation in Best and Bergin's reading cit $n$-armand suggests that it also derives from * cía ata $n$-, but the lack of an independent pronoun would suggest an early date. According to Thurneysen (GOI §815), pronouns inserted before definite predicates are more frequent in the Milan glosses than in the Würzburg glosses, but this nevertheless indicates that the use of the independent pronoun in such constructions was already becoming established by the eighth century. Thus, the phrase provides ambiguous evidence with regard to the date of the poem: citné would indicate a later, perhaps Middle Irish date, while cit $n$-would suggest a date perhaps predating the ninth century. In the text printed here, I have retained Best and Bergin's rendering of the manuscript reading. The sense of the passage remains the same, regardless of how the word is understood.

The text is too short for linguistic analysis to be of much use in dating it, and the loss of text in the margins exacerbates this problem. A terminus ante quem is, of course, provided by the date of the manuscript. The text was written by scribe $M$, who was probably working in the eleventh century, ${ }^{7}$ but it is

\footnotetext{
7 The traditional division of the manuscript undertaken by Best (BEST 1912) is into passages written by scribes $\mathrm{A}, \mathrm{M}$ and $\mathrm{H}$, and recent palaeographical analysis strongly suggests that the hand designated $\mathrm{H}$ by Best in fact represents the work of several scribes (DuncAN 2015). The date at which the medieval scribes were working has been the subject of some discussion. M was originally identified with Máel Muire mac meic Cuind na mBocht, who is recorded as having been killed at Clonmacnoise in AFM, s.a. 1106, but this view was challenged in Ó ConcheANAINN 1974, who argued that $\mathrm{H}$ should be identified with Máel Muire (for the different opinions on the dating of the scribes, see Oskamp 1966-7, OsKamp 1975-6, Ó ConcheanainN 1974, Ó Concheanainn 1984, Mac Eoin 1994 and Breatnach 1996). Despite this, the scribe or scribes designated $\mathrm{H}$, the last to have worked on the manuscript, are likely to have been working at some point in the eleventh or twelfth century (cf. MAC EoIN 1994: 41 for a date for $\mathrm{H}$ after the middle of the twelfth century, OsKamP
} 
clear that the poem predates the manuscript. ${ }^{8}$ The extant text shows Old Irish features but also signs of Middle Irish developments. Cend as a plural is more likely to be Old Irish for two reasons: firstly, the short plural form is used here unaccompanied by an additional plural indicator, ${ }^{9}$ and secondly, as the noun becomes masculine once the neuter gender disappears, one would expect cind in Middle Irish. While most verbal forms (dundánic, from do-icc, indid from ind-fét, góeta from gonaid, danéim from do-eim) are compatible with Old Irish usage, adradnacht, from ad-anaig, shows signs of a Middle Irish shift from the compound verb to the simplified, prototonic form: the $d$ would not be expected if the form were Old Irish. In fact, the form in the manuscript appears constitutes a combination of the Old Irish deuterotonic perfect form of the verb (ad-ranacht) and the prototonic preterite (-adnacht), with the protononic form incroaching on the deuterotonic stressed portion -ranacht and the preverb $a d$ in effect duplicated. This practice is encountered in Middle Irish forms as compound verbs are replaced by simple verbs. ${ }^{10}$

All of the poem's stanzas are affected by the loss of text, but lines 1a, 1c, $2 \mathrm{a}, 2 \mathrm{c}, 2 \mathrm{~d}, 3 \mathrm{a}, 3 \mathrm{~b}$ and $3 \mathrm{c}$ are preserved in their entirety. These lines all consist of seven syllables. The fragmentary lines, $1 \mathrm{~b}, 1 \mathrm{~d}, 2 \mathrm{~b}$ and $3 \mathrm{~d}$, all consisted of at least six syllables. This suggests heptasyllabic lines throughout, especially as there is at least one complete example of each type of line (a, b, c, d), and that consists of seven syllables.

Lines 2cd and 3ab show that rhyme is not between the end-words of a couplet. Instead, although the lack of text means there is no surviving example, end-rhyme is likely to have originally been between $b$ and $d$. Lines $2 \mathrm{~d}$ and $3 \mathrm{~b}$ show that this rhyme was between disyllabic words. Indeed, the majority of complete lines ends in a disyllable (1a, 1c, 2d, 3a, 3b, 3c), the exceptions being the end-word of 2a, Breg, and that of 2c, Conchobuir. Given this reconstructed syllable count and rhyme pattern, the metre of the poem is rannaigecht. Stanzas 1 and 3 have a regular syllable count of $7^{2}$, conforming with the metre rannaigecht bec. ${ }^{11}$ In stanza 2 , on the other hand, this syllable count only applies

1975-6: 182 for a date prior to 1130, and, more recently, BREATNACH 1996: 207 for the suggestion that $\mathrm{H}$ should be dated to the second half of the eleventh century). $\mathrm{M}$, who must be dated earlier than $\mathrm{H}$, was probably working in the eleventh century. Cf. also Máire Herbert's discussion (HERBERT 2007), whose 'working hypothesis is that Lebor na hUidre is an eleventh-century Clonmacnois product' (HERBERT 2007: 92).

${ }^{8}$ Apart from possibly Old Irish features in the text, note the difference in usage between the title and the body of the poem with regard to the relative of attá. The title has the Middle Irish form hi filet, whereas $1 \mathrm{~d}$ of the poem reads hi fil. The latter is more common in Middle Irish, but also appears in Old Irish.

${ }^{9}$ On the distinction in usage between the long and the short form, see GOI $\$ 278$. It might be considered, however, whether metrical restraints may have influenced usage here.

${ }^{10}$ For examples, see Breatnach 1994: 284, §11.20.

11 See Meyer 1909: 13, no. 32.2, and Murphy 1961: 53, no. 16, and comments on nos 15 and 16. 
to lines $b$ and $d$, whereas line $2 \mathrm{a}$ has a syllable count of $7^{1}$ and line $2 \mathrm{c}$ has a count of $7^{3}$. This variation is not unusual and is found in other rannaigecht peoms. ${ }^{12}$

Disyllabic end-rhyme between b and d underlies Best and Bergin's suggestions for the text lost, and in stanza 3, the lost text can hardly have been anything other than fadesin, ${ }^{13}$ further supporting end-rhyme between $\mathrm{b}$ and $\mathrm{d}$. This supposes rhyme between isil and fadesin, which is problematic and suggests that either fadesin should be fadisin 'herself', agreeing with feminine Emain, or that isil should be essil. ${ }^{14}$

Line $3 \mathrm{~b}$ is very problematic and I have left it untranslated below. A tentative attempt to make sense of it is the translation 'guilt [is] the fetter of every point of his ignorance/lowliness', taking the line as a zero-copula clause and emending isil to essil, genitive of a substantivised form of essel ('astray (?)', 'ignorant '). ${ }^{15}$ Cinid would have to be read as two seperate words, cin ('guilt', 'crime', 'liability') and id ('fetter', 'chain', 'collar'). ${ }^{16} \mathrm{Ha}$ would be taken as the 3 sg. possessive pronoun, with the $h$ not serving any function (cf. GOI §25). The sense of the line and its syntactic connection to the rest of the stanza when translated in this way are, however, questionable.

Best and Bergin's suggestion of Achi as the last word in $2 \mathrm{~b}$ must be based on assumed rhyme with Machi, but I have been unable to find references to a placename Túath Achi, and it must be noted that Best and Bergin only suggest this reading tentatively, adding a question mark. ${ }^{17}$ In $1 \mathrm{~d}$, the damaged end-word

12 See the comments in Murphy 1961: 52 and the list in BreAtnach 2015: 58 (entries under the heading 'Mixed rannaigecht').

13 Meyer initially printed 'fa des ...' (1906: 44), but the 'Further addenda and corrigenda' of the 1937 reprint show that he later entered the note 'leg. da-n-eim fadēs[in]' in his copy of the text. It is possible that one might read fa des [sin] 'to the south of [that]', suggesting a location south of Emain, which would tally with the location of Blaî's death given in STOKEs 1902: 308, §15 (I am grateful to Jürgen Uhlich for this suggestion). On balance, however, given that there are textual problems with the stanza as a whole and that there is no necessity for Blaí's head to have been buried where he died, it would be speculative to translate the text in this way here.

${ }^{14}$ From essel, -il 'astray (?)'; 'ignorant'. For the feminine form fadisin, cf. DIL F 4.46 and F 4.59-60. Despite this form not surviving into the Middle Irish period, this reading may be valid as the form fadesin may represent scribal intervention and updating to a more familiar form.

${ }^{15}$ In addition to essil, another possibility, if reading fadisin in $3 \mathrm{~d}$, is that the second $i$ is long (see GOI $\S 485$ for this suggestion as well as SCHRIJvER 1997: 76), in which case isil stands for isil (from isel 'low', 'humble', 'low-lying', 'mean'), but it is unclear how it would be translated.

16 The first word of the line, cinid, could, formally, be interpreted in several different ways: 1. as cía plus the negative particle plus the $3 \mathrm{sg}$. pres. ind. of the copula ('though it is not'); 2. as the verb cinid ('is born, descends from'); 3. as a form of ciniud, the verbal noun of cinid ('offspring', 'descendants'). Furthermore, if reading cin id, id may also be the unattested genitive of ed ('space', 'distance', 'length'). It is difficult to see how any of these would result in a meaningful translation.

${ }^{17}$ I take tuaith as a dative in apposition to Raith Emnae. Alternatively, as Jürgen Uhlich 
must be Ulad, given the poem's heading, and the suggestion churach for $1 \mathrm{~b}$ makes good sense.

Accepting Best and Bergin's emendations, my tentative translation of the poem is as follows:

Tell me what the places are in which the heads of the champions of the [Ulstermen] are, from the time when Fáilbe came to us, in Delíu (?), ${ }^{18}$ after travelling [by boat]. ${ }^{19}$

The head of Conchobar was buried with his body ${ }^{20}$ in Macha after having been brought from ${ }^{21}$ Mag mBreg to the Ráth of Emain, [to] Túath A...

has suggested to me, it would also be possible to read túaith 'north of'. Given the uncertainty in the reading of the word beginning with $A$-, however, and given that I have not been able to localise the place in question, one cannot be certain how to translate the word. The closest placename I have been able to find in HogAN 1910 is found in cath Ache (s.v. ache), which is referenced in a poem in the Book of Leinster (LL 23502). Hogan does not identify the location of cath Ache, but locations of other battles mentioned in the lines before and in the same lines as cath Ache are given as Meath or Leinster (cath Oche) and Kildare (cath Uchbath) by Hogan (see HogAN 1910, s.vv. ocha and ucha). Hogan also provides a reference to tuath [s.v.] achda / tuath Athachda, a group which he locates east of the Liffey to the sea. In none of these instances is it clear how the places would connect to the information found in the extant accounts of Conchobar's death.

${ }^{18}$ I have taken dundánic as containing a 1 pl. class A infixed pronoun (with nd as a spelling for $n n$ ) and read 'when Fáilbe came to us, in Delíu', with Deliu as an independent locative dative (see below, n. 21). Although the clause is relative, class $\mathrm{C}$ infixes are not always used in the 1 and 2 persons (GOI $\S 413$ and McCone 1994: 199-200). It might also be possible to take Delíu as a short $n$-stem accusative (either influenced by the dative form or by the paradigm of $i \bar{a}$-stem nouns; see STÜBER 1998: 14 and 16) if one understands it as an apposition ('...from the time when Fáilbe came to it, Delíu...'). In this case, the infixed pronoun would have to be a proleptic $3 \mathrm{sg} . \mathrm{n}$. class $\mathrm{C}$ infixed pronoun and Deliu must be neuter. This is problematic as a nominative ending in $-i u$ is more likely to be feminine (cf. GOI $§ 328$ and §332).

19 Churach is a genitive plural; hence, a literal translation would be 'after rowing boats'.

${ }^{20}$ Literally, 'upon his body'.

${ }^{21}$ If this word is to be taken as a reference to the place found in Hogan 1910 s.v. Delenn and if Hogan's suggestion of a nominative singular Deliu is correct, the noun is an $n$-stem. The preceding entry Delend, although apparently a different place, appears to have the same form and may also have the same nominative; note that DIL lists this place under 2 Deilenn. Grammatically, Delíu cannot be a nominative here. An accusative might be expected if the infixed pronoun in dundánic refers proleptically to the word, but while there are $n$-stem nouns that show accusative singular forms in $-u$, Deliu is unlikely to be neuter (see n. 18 , above). It is, therefore, more likely to be a short dative singular, in which case it would have to function as an independent dative here, although this is found only rarely with a locative meaning (see GOI §251.3). The length-mark is also problematic, as one would not expect the ending to be long. It is possible that it is accidental, and I can offer no other explanation of 
He [Blaí] was wounded because of the wife of Celtchar although it is not every ... After trouble, ${ }^{22}$ [it is] the head of Blaí Briugu which Emain itself conceals. $^{23}$

\section{Content and related tales}

The poem, as it survives, refers to the deaths of Conchobar and Blaí Briugu. The first stanza provides the context in which the information the poem conveyed is supposed to have been received. Fáilbe appears to be a personal name, and the stanza also contains a $2 \mathrm{sg}$. imperative, but it is unclear at whom this directed. It is possible that this is an instance of person-switching and that Fáilbe is the addressee of the first stanza as well as being referred to in the third person. ${ }^{24}$ However, the first words of the poem, Hond úair, indicate that the burial places to be related post-date the arrival of Fáilbe. Thus, it seems more likely that he or she, rather than being the addresse of the poem, is a character from the pre-Christian past who is used to identify the timeframe to which the poem refers. ${ }^{25}$ I have not been able to identify this Fáilbe, but it should be noted

it. Because of the problems associated with the word, I have placed a question mark in the translation.

${ }^{22}$ Insu is taken as a dative of the substantivised form of ansae or ins(a)e. I have translated it here as 'trouble', without specifying what it refers to. As suggested to me by the reviewer, it may refer to the geis under which Blaí is and which ultimately leads to the conflict with Celtchar and Blaí's death, but iar n-insu may also refer to the hostility between Blaí and Celtchar.

${ }^{23}$ Danéim is here taken as a nasalising relative of do-eim. The length-mark on the $e$ would have to be considered spurious, but there are other examples of irregular length-marks in passages written by M (see, for example, cómfocus, LU 1. 1976, and fóscugud, LU 1. 1985); if 'Delíu' in 1b is in fact a placename Deliu, as suggested above, it represents a further example of a spurious length-mark as final unstressed vowels are not long in Old Irish. Another possibility would be to take the form as containing an infixed pronoun, with cend Blai Briugad iar n-insu as a nominativus pendens group ('the head of Blai Briugad after trouble, Emain itself hides it'). The problem here is that the infixed pronoun would be masculine, but the plural chend in $1 \mathrm{~d}$ must be neuter. The sense of lines $3 \mathrm{~d}$ and $\mathrm{c}$ remains the same with both interpretations of the form daneim, though the translations are slightly different.

24 As has been suggsted to me by the reviewer. On this feature of Irish and Welsh poetry, see Sims-Williams 2005.

${ }^{25}$ Unless one posited that Fáilbe was akin to the figure of Fintan mac Bóchra, who arrived in Ireland before the flood and survived into Christian times and to whom historical knowledge and numerous poems are attributed in different texts, for example, Lebor Gabála Érenn (MACALISTER 1938-56) and Suidigud tellaig Temra (BEST 1908-10). In Lebor Gabála, God is said to have protected Fintan conidh he ro innis gabāla Ërenn, 'so that it was he who related the Takings of Ireland' (MAcAlister 1938-56: II, 194-5, §185), and in Suidigud tellaig Temra it is Fintan's old age and good knowledge of history that make him a suitable judge for the conflict between Díarmait mac Cerbaill and his nobles that opens the story; see, e.g., Fintan's claim that 
that a female Failbi occurs in Lebor Gabála Érenn as one of the people who accompanied Cessair and, furthermore, that one of the sons of Mananán is called Failbi Findbuide. ${ }^{26}$ In neither case has a connection with a place called Delíu been transmitted. Nevertheless, a connection with characters in Lebor Gabála is more likely to be correct than a connection with one of the numerous individuals of the Christian period called Fáilbe. ${ }^{27}$

Delíu may be the place referred to as Campus Delenn in Chronicon Scotorum, which Hogan locates near Glencolumbkille. ${ }^{28}$ Alternatively, the previous entry in his Onomasticon, Delend, probably located in Scotland, may also be meant. In both cases, a journey by boats is plausible. Deilenn is also given as an $o^{-}$or $n$-stem personal name in DIL (s.v. 1 Deilenn), but given the explicit reference to travel by boats, a placename makes greater sense here.

Accounts of Conchobar's death appear to have been popular, judging by the different surviving versions of his death-tale. ${ }^{29}$ Blaí Briugu's death is recounted in the tale Aided Cheltchair maic Uthechair, edited by Kuno Meyer. ${ }^{30}$ Both dead heroes are also referred to in Cináed úa hArtacáin’s poem Fíanna bátar $i$ nEmain. ${ }^{31}$ Conchobar dies when he hears about Christ's crucifixion. ${ }^{32}$ His emotions at the news are so strong that Mess Gegra's calcified brain, which has been

am éolach ina fesaib 7 ina táintib 7 ina toglaib 7 ina tochmorcaib do neoch dorónad díb o dílind ille, 'I am skilled in its [Ireland's] feasts and its cattle-spoils, its destructions and its courtships, in all that have taken place from the Deluge until now' (BEST 190810: 128-9, §8), and the poem Héiriu cía fíarfaidir dím, which Fintan recites (text and translation: BEST 1908-10: 128-33, §9). For a survey of Fintan's portrayal in a range of texts, see Nic CÁrthaigh 2007. With regard to Fáilbe, however, this comparison remains speculative without any further indications as to his or her identity.

26 On the Failbi associated with Cessair, see MAcAlister 1938-56: II, 208 and 226. Failbi Findbuide is also referred to in Lebor Gabála Érenn (see MACALISTER 1938-56: IV, 190).

27 There are, for example, several saints called Fáilbe; see Ó RIAIN 2011: 301-2. Moreover, this is also the name of a seventh-century king of Munster, Faílbe Flann (see CHARLESEDWARDS 2000: 498-9).

${ }^{28}$ Hogan 1910 s.v. Delenn; see Hennessy 1866: 120, s.a. 717.

29 The tale is edited in Meyer 1906. Meyer did not include all the manuscripts of the tale in this edition, although he published one of the additional manuscripts in MEYER 1921. Kobel 2014 provides a new, complete edition of the tale.

30 MEYER 1906: 24-31. The structure of this tale and the role of the dogs referred to in it are discussed in McCone 1984.

31 The poem is edited and translated in STOKEs 1902. The reference to Conchobar is in st. 4 (p. 304) and that to Blaí in st. 15 (p. 308). On the authorship of the poem, see Murphy 1952: 151-6, who concludes that Cináed is likely to have composed it.

${ }^{32}$ Version A as preserved in the two Edinburgh manuscripts of the tale explicitly refers to Conchobar's death. The texts in the Book of Leinster and Dublin, Royal Irish Academy, C i 2 (1234) do not, but the use of the title Aided Chonchobair in the Book of Leinster at least indicates that the king's death was assumed. For a possible reason as to why these two manuscript versions differ from the others in this regard, see IMHOFF 2012. 
lodged in his head since Cet used it to shoot him, falls out, causing his death. The versions of his death-tale are a good illustration of the fact that different details concerning a famous individual's death and burial could circulate. ${ }^{33}$ Not only are different storylines preserved, but it is possible that the version designated A by Meyer preserves the ending of an earlier version, in which Conchobar died in battle. ${ }^{34}$ None of the versions refer to Conchobar being buried at Emain Macha, a claim made in Inna hinada, nor is his death ever said to have taken place in Mag mBreg. There are indications that Conchobar was believed to have died in the territory of the Fir Rois, which would have been close to Mag mBreg. The information in the versions of Aided Chonchobair regarding the place in which Conchobar died varies, not taking into account the possible preservation of an earlier ending in the A-version manuscripts, and the location of the places referred to is not always certain. ${ }^{35}$ However, the variation seen across the versions of Aided Chonchobair means that Inna hinada's introduction of details not found in the versions of Conchobar's death-tale should not, perhaps, come

${ }^{33}$ For a discussion of the different extant versions, see Iмноғ 2012.

34 For this argument, see CARNEY 1955: 296 as well as Szövérffy 1956: 201-2 (SzÖVÉRFFy 1957 is a translation of SzÖVÉRFFy 1956) and GuYONVARC'H 1958: 135. The king's grave is said to have been for brú Átha Daire Dā Báeth (MEYER 1906: 6). As far as I am aware, this place has not been identified.

${ }^{35}$ Not all of the manuscripts name the place of his death or even refer to his death; in the other manuscripts, Conchobar dies at an unnamed place by the seashore following a frenzied rage (MEYER 1906: 16) or at Mag Lámraige (see MEYER 1906: 11, n. a, and p. 18; Mag Lámraige also appears to be Conchobar's place of death in Edinburgh Adv. 72.1.5 (fo. 8ra), not included in Meyer's edition, though the text is barely legible at this point). Mag Lámraige, according to at least one of the Edinburgh manuscripts, is in the territory of the Fir Rois (Meyer 1906: 11, n. a). A gloss on Fíanna bátar i nEmain in Egerton 1782 identifies the forest cut down by Conchobar in his frenzy as Fidh Lámraige (STOKEs 1902: 323), and Keating names the forest as Coill Lamhruidhe, which he also places in the territory of the Fir Rois (Keating II: 202, 204). In addition to this localisation of the forest, Edmund Hogan cites Eugene O'Curry for the identification of Coill Lamhruidhe as being near Emain Macha (HogAN 1910: 281, s.v. 'coill lamhruidhe', referring to O'CuRry 1861: 277), but it is not clear to me on what source O'Curry drew for this statement. In addition to these indications, Conchobar's death is stated as occurring for toeb Letrach Lamraigi, dos-cel Slea Sliab co rath, 'on the side of Letir Lamraige. Mount Slea graciously hides him', in the main text of Fíanna bátar i nEmain (STOKEs 1902: 304, 305). One would assume that Lettir Lámraige and Mag Lámraige, and consequently Coill/Fid Lámraige, are likely to be in close proximity to one another, but another gloss on the stanza in Egerton 1782 (see Stokes 1902: 323) states that Sliab Slea is situated in the territory of the Ulaid, on Loch Laíg, which in turn may be identified with Belfast Lough (see STOKEs 1902: 323, for the gloss, and Stokes's comments on p. 332 for the identification of Loch Laíg with Belfast Lough). This gloss is also cited by Hogan as the only indication of where Sliab Slea was situated (see Hogan 1910: 611), and he also identifies Loch Laíg with Belfast Lough (see Hogan's first entry for Loch Láig, HogAN 1910: 500). 
as a surprise. ${ }^{36}$ What is significant, however, is that in none of the references to Conchobar's death of which I am aware is he said to have been beheaded. This is a point to which I will return.

Turning to Blaí Briugu, his death, according to the account in Aided Cheltchair maic Uthechair, comes about after he commits adultery with Celtchar's wife. ${ }^{37}$ Blaí does this because he is under a geis which stipulates that he must sleep with any woman who comes to his guest house as part of a visiting company without her husband. Celtchar takes revenge by killing Blaí while he is watching a game of fidchell between Conchobar and Cú Chulainn. The reference to Celtchar's wife in the poem above indicates that the same story underlies the poem, and the mention of difficulty or trouble (iar n-insu) may be a reference to Blaí's geis and the unfortunate situation in which he finds himself as a result, namely his being forced to commit adultery, or it may refer to Celtchar's hostile action towards Blaí. The account of Blaí's death in Aided Cheltchair suggests that Blaí died at Emain Macha: Luid Blāi briuga co mbái for lethláim Conchobair isin rígthig. ... clannaid Celtchar in gái trit co mbái isin cleith iarna cúl ... Atbath immorro Blai briuga', 'Blái the Hospitaller went until he was by the side of Conchobar in the royal house.... Celtchar plants a spear through him so that it stuck in the wattle of the wall behind him. ... Blái the Hospitaller, however, died'. ${ }^{38}$ This would agree roughly with Cináed's statement in stanza 15 of Fíanna bátar i nEmain that Blaí died near Emain Macha: bás Blai Briuga tria chin mná / i ndesciurt Oenaig Macha, 'Blai Briuga's death through his adultery (was) in the south of Oenach Macha'. ${ }^{39}$ Neither source, however, provides corroboration for the information from the Inna hinada poem that Blaí was also buried at Emain Macha, and, as in the case of Conchobar, there is no reference to Blaí being beheaded, although his death, unlike Conchobar's, is the direct result of a hostile attack. ${ }^{40}$

${ }^{36}$ It is possible that the references to Art mac Cuind's burial in different texts constitute a further example of variation regarding the death and burial of a famous individual (for a discussion of texts referring to Art's burial place, see IMHOFF 2013: 75-89).

37 For an edition and translation of Aided Cheltchair maic Uthechair, see Meyer 1906: 24-31.

38 MEYer 1906: 24-5.

39 STOKEs 1902: 308-9. Oenach Macha should be identified with Emain Macha: the dindshenchas poem on Armagh refers to óenach Macha (Gwynn 1903-35: vol. IV, 124, 1.20), which indicates that it was at least in the vicinity of Emain Macha, and the prose dindshenchas of Ard Macha also refers to óenach Macha (STOKEs 1895: 45; referred to by STOKES 1902: 336).

40 If one accepts the argument that version A of Aided Chonchobair preserves an earlier version of the king's death-tale, there was also a tradition of Conchobar having died as a result of an attack. However, the brief glimpse of this ending that may be afforded by A does not suggest a beheading. Conchobar dies when Mesgegra's brain enters his head: Nosindlethar Cet inchind Mesgegra isin tábaill 7 nosteilc conidtarla immullach Conchobuir co mbátar a dā trīan inna chind 7 co torchair-seom isa cend, co tarla fri lár. Forcherddat Ulaid chuci conidrucsat ō Chet. For brú Átha Daire Dā Báeth is and 


\section{Burial places and heads}

Overall, the poem, though fragmentary, is an example of the interest taken in the burial places of supposedly historical figures in early Irish literature. This interest is exhibited elsewhere, both in prose and verse, including in a number of other Lebor na hUidre texts, most obviously Senchas na relec. ${ }^{41}$

More particularly, the heading of the Inna hinada poem quite explicitly states that it concerns the places in which the heads of the Ulster champions are buried. This is striking given that, as stated above, other surviving sources do not indicate that the either Conchobar or Blaí were believed to have been beheaded. Stanza 2 highlights the fact that the head is the part of the body in which the poet is interested when it offers us the information that Conchobar's head was buried on his body. This is a strange statement, given that one would not expect the head to be buried anywhere else, and it can only be explained as illustrating the poem's particular focus on the head.

The significance of heads in medieval Irish literature has, of course, been discussed with reference to an apparent pre-historic Celtic cult of the head. ${ }^{42}$ Archaeology, classical textual sources, and medieval Irish and Welsh literature have been cited as sources for such a head cult. As a result, an apparent focus on the head in other contexts has also been associated with the idea of a Celtic head cult. For example, certain severed heads in Old Norse literature have been connected to Celtic influence, ${ }^{43}$ and the relatively reserved treatment of Oswald's head relic in Northumbria has been connected to the survival of preChristian Celtic beliefs. ${ }^{44}$ However, the idea of a Celtic head cult has come under criticism, not just because of methodological problems involved in using the surviving medieval literature as a source, and it is important to note that heads in general, and severed heads in particular, hold fascination and symbolic value in cultures around the world. ${ }^{45}$ In the text under discussion here, it is

dorochair Conchobar. Atá a lige and baile i torchair 7 corthe fria chend 7 corthe fria chossa, 'He [Cet] adjusts the brain of Mesgegra in the sling, and throws it so that it hit the crown of Conchobar's head, so that two-thirds of it entered his head, so that he fell upon his head forward to the ground. The men of Ulster ran towards him, and carried him off from Cet. On the brink of the ford of Daire Dá Báeth it was that Conchobar fell. His grave is there where he fell, and a pillar-stone at his head, and another at his feet', MEYER 1906: 6-7.

${ }^{41} L U, 11.4040-4204$; the text also survives in the fifteenth-century TCD MS 1336 (H.3.17), col. 731-4.

42 See, for example, Ross 1967 (rev. ed., 1992), chapter 2 'The cult of the head', as well as Ross 1970: esp. 154-8.

${ }^{43}$ For references, see SigurĐsson 1988: 81-2 (section 6.2.6 'Talking heads').

44 Thacker 1995: 102.

45 A useful discussion illustrating this is found, along with further references to contributions on the topic, in Sims-WiLliams 2012: 3-7. Criticism of the conclusions drawn from the archaeological and classical textual evidence, and of the idea of a head cult in particular, has been voiced by a number of scholars, for example, Bernhard MAIER 
clear that the heads cannot be connected to a Celtic head cult. For one thing, passages cited as evidence of a Celtic interest in heads deal with beheadings in the context of hostilities. Furthermore, in medieval Irish literature more generally, decapitation is frequently an act of humiliation for the enemy as well as his kingroup, as when, for example, Conall Cernach brandishes Ánlúan's head dramatically in Scéla Mucce meic Dathó. ${ }^{46}$ As far as it is possible to tell, the Inna hinada poem is not negative in tone and it does not appear to have been composed from the point of view of people who would have considered themselves in opposition to what or whom the Ulster characters mentioned represented. Blaí does die as a result of hostility, but as stated above, surviving sources do not indicate that there was a tradition of his having been beheaded. With regard to Conchobar, although he ultimately dies as the result of an enemy attack, his death is, on the whole, not viewed negatively. He dies as a result of his faith in Christ and he is said, in some of the versions of his death-tale, to have gone to heaven. ${ }^{47}$

Thus, the focus on heads in the Inna hinada poem is unlikely to reflect shameful defeat in battle. Instead, the emphasis on heads in the poem can be connected to traditions concerning the importance attached to different body parts in classical times and the Middle Ages, and more particularly the idea that the head represented the principal part of the body. ${ }^{48}$ This status was also at times assigned to the heart, and the question was not simply a medical matter in the modern sense but also a philosophical and theological question. The functioning of the body was what was at issue, but it was also related, for example, to questions concerning the soul and what actually governed the body's movement, senses, thoughts, etc. ${ }^{49}$ Different views were held, sometimes in one and

(2000). He also addresses the question of a peculiarly Celtic head cult (MAIER 2000: 12-13), as do John Collins (2003: 215-16) and Naoko Shirai, who, though she states that the Celts had a particular interest in heads, draws attention to the fact that decapitation and severed heads are not uniquely Celtic motifs (SHIRAI 1997: 315-27). Aside from decapitation as punishment or a way of shaming an enemy, found in other cultures and periods (for example, in the case of John the Baptist), unusual severed heads are found outside the Celtic areas, too. In a medieval European context one example is cephalophoric saints, of whom St. Denis is probably the best known example. On decapitation and the severed head in European medieval and early modern culture, see the contributions in Tracy \& MASSEy 2012 and SANTing, BAERT \& Traninger 2013.

46 See Thurneysen 1935: 16, §16.

47 This is stated in the versions of Aided Chonchobair in Adv. 72.1.5, Adv. 72.1.40, RIA $23 \mathrm{~N} 10$ and the Liber Flavus (cf. MEYER 1906: 10 (n. 27), 14 and 16, and summary table in IMHOFF 2012: 45-6).

${ }^{48}$ For a discussion of the significance of heart, head and hand, see SCHMITZ-EsSER 2014: 631-51.

49 There is a great deal of secondary literature on the role of the heart, head and other organs and the organisation of the body in medieval medicine. For an outline of medieval positions, see, for example, Weвв 2010: 19-26, and Cohen 2013: esp. 64-70. 
the same text,$^{50}$ making their way also into narrative texts. The primacy of head or heart also played a role in the political use of bodily metaphors, as has been outlined by Jacques Le Goff and others. ${ }^{51}$ Le Goff argues that Greco-Roman tradition and the Christian concept of the church as one body with Christ as the head, as found in the Pauline epistles, influenced the use of body metaphors in a political context in the Middle Ages, ${ }^{52}$ stating that 'In successive phases, these metaphors became politicized during the Carolingian period, then during the Gregorian reform, and finally during the twelfth century, which was particularly enamored of this comparison'. ${ }^{53}$ In addition to the biblical examples which place the head at the top of a bodily hierarchy, an example from Isidore's Etymologies, known, at least in parts, in Irish circles from the seventh century, ${ }^{54}$ shows that the idea of the head as the primary body part could have been known in Ireland from an early date:

Prima pars corporis caput; datumque illi hoc nomen eo quod sensus omnes et nervi inde initium capiant, atque ex eo omnis vigendi causa oriatur. Ibi enim omnes sensus apparent. Vnde ipsius animae, quae consulit corpori, quodammodo personam gerit,

'The primary part of the body is the head (caput), and it was given this name because from there all senses and nerves originate (initium capere), and every source of activity arises from it. In it, all sensations become evident. Whence it plays the role, so to speak, of the soul itself, which watches over the body' ${ }^{55}$

50 See CoHen 2013: 69.

${ }^{51}$ Le Goff 1989: 13-26. The question is also discussed with a particular emphasis on chronology in SHogimen 2007 and Cohen 2013, who disputes Shogimen's chronology (CoHen 2013: 73).

52 LE Goff 1989: 13-14. Two examples cited by Le Goff are Rom. 12.4-5, which refers to the faithful as one body, and Eph. 5.23-4, which establishes Christ as the head of the body that is the church (see LE GofF 1989: 23-4, n. 3), and the metaphor also occurs elsewhere in the New Testament epistles (for example, Eph. 4.11-13 and 15, and Col. 1.18).

${ }^{53}$ Le Goff 1989: 16.

${ }^{54}$ St. Gall, Stiftsbibliothek MS 1399.1.a, and flyleaves in Longleat House, Marquess of Bath, NMR 10589, dated to the seventh century and the late seventh or early eighth century, respectively, represent early fragments of Isidore's Etymologies, the script of which associates them with Ireland, although this does not necessarily mean they were written in Ireland. On the St. Gall fragment see, amongst others, BischofF 1966: esp. 180, and on the Longleat House fragment, see CARLEy \& Dooley 1991 (see p. 144 for the date of $680 \times 700$ ). On the transmission of Isidore's work to Ireland more generally, see, for example, Hillgarth 1984 and SMYTH 1987, the latter of whom cautions against assuming that a full version of the Etymologiae was known in Ireland in the mid-seventh century.

55 Isidore, Etymologiae XI.i.25, ed. LINDSAY 1911: vol. II; trans. BARNEY et al. 2006: 232. 
The head's status as principal body part is linked in classical and medieval sources to the idea that the burial place of the head determined which location was to be considered an individual's burial place in cases in which a person's body parts had been interred or preserved in different places. ${ }^{56}$ Paulus, a late second-/early third-century Roman jurist, ${ }^{57}$ is cited in the sixth century in Justinian's Digest as claiming that, because the head is the principal part of the body, the location of the head's burial determines the sanctity of the burial place:

Cum in diuersis locis sepultum est, uterque quidem locus religiosus non fit, quia una sepultura plura sepulchra efficere non potest: mihi autem uidetur illum religiosum esse, ubi quod est principale conditum est, id est caput, cuius imago fit, inde cognoscimur.

'When burial has been performed in more than one place, the places are not both made religious, because one burial cannot produce more than one tomb. In my opinion, the place which is religious is the one where the most important part of us is buried, that is the head from which likenesses are made, by which we are recognised'. ${ }^{58}$

In the twelfth century, one finds an echo of Paulus's statement, when Iohannes Beleth in his Summa de ecclesiasticis officiis repeats this idea, as in the following:

Religiosus dicitur secundum leges et instituta Romanorum omnis locus, in quo sepelitur corpus hominis siue caput tantum. Caput ideo dico, quia nullus homo potest habere duas sepulturas, sed ubi caput, ibi dicitur esse sepultura eius. $^{59}$

'According to the laws and statutes of the Romans, every place, in which the body or just the head of a person is buried, is considered to be consecrated. I say the head because no person can have two burials, but where the head is, that is where his burial is said to be'.

The idea that the place of the head's interment represented an individual's burial place must have had great relevance in a context in which both ecclesiastical and lay individuals could sometimes be buried in multiple places. In the cases of saints, whose relics could be found distributed between different foundations, the significance is obvious, but secular rulers could also be buried in multiple locations. Apart from mutilation that might occur in battle, deliberate division

\footnotetext{
56 WAlker Bynum 1995: 178, n. 73, and 201, n. 4, and SChmitz-EsSER 2014: 640-1, who also cites the passages from Justinian's Digests and Johannes Beleth cited here.

${ }^{57}$ For a concise summary of what is known about Paulus, see DU PLEssis 2010: 49.

58 Digest XI.7.44, see Mommsen, Krueger \& Watson 1985, vol. I.

59 Beleth, Summa de ecclesiasticis officiis, ch. 159; ed. DouteIL 1976: 304.
} 
of the body, especially a royal body, was also undertaken in the Middle Ages. ${ }^{60}$ Initially this was probably undertaken for practical reasons when an individual died at some distance from the intended burial place. Attempts could be made to preserve the body, but the internal organs were usually removed. ${ }^{61}$ Another practice, developed by the middle of the twelfth century and eventually known as mos teutonicus, was to boil the body down and to transport only the bones, ${ }^{62}$ a practice which prompted a papal bull by Pope Boniface VIII prohibiting it. ${ }^{63}$ Connected to these developments was the practice of individuals of high status requesting that different parts of their bodies should be buried in different locations, often as a sign of personal attachment or favour to a particular foundation. ${ }^{64}$ While this appears to have been primarily a later medieval phenomenon, preservation of the body for transportation is attested as early as the ninth century for Charles the Bald, ${ }^{65}$ and in the eleventh century, the Emperor Henry III chose to be buried in different places. ${ }^{66}$

The primacy of the head, but more specifically, the significance of the burial place of the head, is reflected also in early medieval Irish texts. Political metaphors such as those discussed by Le Goff may be discernible in Togail Bruidne Da Derga, if one follows Amy C. Eichhorn-Mulligan's reading of the tale, which emphasises the metaphor of a political unity as a body. ${ }^{67}$ Mulligan has considered the descriptions of bodies and of dress in Togail Bruidne Da Derga against the background of a focus on the body in medieval Irish texts more generally, stating that "the visible body was "read" and its physical attributes invested with significance that extended far beyond issues of mere corporeality'. ${ }^{68}$ With regard to Togail Bruidne Da Derga, she sees Conaire's head as a metaphor for authority and Conaire's position itself: 'As the physical embod-

${ }^{60}$ For a very useful overview of different individuals whose bodies were treated in this way, see SCHÄFER 1920.

${ }^{61}$ For references to this practice and to the burial of body parts in different places, see Paravicini Bagliani 2001: 328, Brown 1981: esp. 226-35, Finucane 1981: 46 and Hallam 1982: 364. WARnTJEs 2012 focuses on the separate burial of body and heart, in particular, but also discusses evisceration in detail, with a particular focus on the anatomical knowledge necessary to perform such an operation and on the significance of contact with the Byzantine world (WARNTJES 2012: 204-10). I am grateful to Máire Ní Mhaonaigh for drawing my attention to this article.

62 Brown 1981: 227, Warntjes 2012: 199 and brief comments in Finucane 1981: 46.

63 On Boniface's bull and on the mos teutonicus, see Paravicini BAgliani 2001: esp. 332-4, Brown 1981 and Brown 1990. WARntJes (2012: 224) also briefly addresses Boniface's bull.

${ }^{64}$ See, for example, Paravicini Bagliani 2001: 329-31, Brown 1981: 227-35, Brown 1990: 809-11, Finucane 1981: 46, Hallam 1982: 364-6, Warntjes 2012.

${ }^{65}$ See, for example, Paravicini Bagliani 2001: 328, Brown 1981: 226 and Warntjes 2012: 206.

66 See, for example, Brown 1981: 228, Brown 1990: 809 and WARntJes 2012: 209.

67 EichHoRN-Mulligan 2005.

68 EichHorn-Mulligan 2005: 5. 
iment of the state, his [Conaire's] crimes are then reflected in the treatment which his own corporeal body receives, and Conaire's head - earlier in the text the descriptive focus and the most important part - is dramatically chopped off in the third scene from the end. ${ }^{69}$

Theologically, the idea of the head as the main part of a person was also significant. Máire Johnson, in a discussion of recapitation in Irish hagiographical texts, suggests that 'a subset of medieval Irish may have viewed the head as the location of the human soul'. ${ }^{70}$ While the question of whether the head was the seat of the soul is related to the idea of the head as the principal part of the body, the discussion above has shown that this idea is not uniquely Irish, although it is found in a number of Irish sources.

Johnson and others have drawn attention to a passage in the Collectio canonum Hibernensis, which claims that all the parts of the body will be gathered together in the place in which the head is. ${ }^{71}$ Another text, which appears to reflect the same idea, is the Latin Life of St Fintan of Clonenagh. The text forms part of the O'Donohue group of lives in the Codex Salmanticensis, the date of which has been placed as early as the eighth century but has also been assigned to the twelfth-century. ${ }^{72}$ The emphasis in the relevant passage of the life is specifically on the burial location of the head. ${ }^{73}$ In the passage in question, the heads of certain laymen, who were victims of a killing, are buried amongst the graves of the monks. When one of the brethren asks in what way this might benefit the dead men, Fintan and Cainnech respond as follows:

Nos credimus et confidimus in Dominum misericordem, quod viri isti in die iudicii non cruciabuntur, propter merita sanctorum et propter honorem

${ }^{69}$ EichHoRn-Mulligan 2005: 16.

70 JoHNSON 2007: §31.

71 Johnson 2007: §31, Charles-Edwards 2000: 527, n. 22 (referring to Elizabeth O’Brien), REKDAL 2011:260. The passage in the Collectio canonum Hibernensis is found at xlix.10 (WASSERSCHLEBEN 1885: 206).

72 Richard Sharpe has argued that this group was compiled in the late eighth or early ninth century (SHARPE 1991: 329), and Máire Herbert has also proposed an eighthcentury date (see, for example, HeRBERT 2001: 337). Sharpe's dating has come under criticism by some and John Carey has proposed a Middle Irish date for the compilation of the group (CAREY 1993: 262). With regard to Fintan's Life in particular, Ingrid Sperber has dated it tentatively to the 730s (SPERBER 2004: 40 and 42). However, Pádraig Ó Riain, having previously cited features in Fintan's Life which point to a comparatively late date (Ó RIAIN 2011: 339-40), has recently argued that the O’Donohue collection is likely to be significantly later (Ó RIAIN 2013: 38-52); while Ó Riain does not provide a precise date, he believes that the arguments which he presents 'point to a date in the twelfth century at the earliest for the O'Donohue Lives' (Ó RIAIN 2013: 49).

73 Charles-Edwards also includes a reference to the passage in question (see CHARLESEDWARDS 2000: 527, n. 22). 
huius loci sancti, in quo principalis pars corporum eorum, silicet capita, sepulta sunt. ${ }^{74}$

'We believe and trust in the merciful Lord that these men will not be tormented on the Day of Judgment, on account of the merits of the saints and on account of the honour of this sacred place in which the chief part of their bodies, that is the heads, are buried'.

While this passage does not contain the same assertion that the head's place of burial is the true location of an individual's burial, it suggests a special significance for the site of the head's interment, namely that this is the site that will influence a person's resurrection and salvation. Given the link made between burial place and resurrection, as witnessed, for example, in the desire to be buried close to saints (burial ad sanctos) or in saints' Lives in which the saint's foundation and future burial place is called the place of his resurrection, the burial place of the heads in the Vita S. Fintani represents the burial place of the entire individuals in question. ${ }^{75}$

A similar belief to that illustrated by the passage from St Fintan's Life may be expressed in the burial of Díarmait mac Cerbaill's head at Clonmacnoise and his body at Connor, as reported in Clonmacnoise-derived annal entries. ${ }^{76}$ If the head was considered more important, it is unsurprising that Clonmacnoise sources would include this information. Susan Leigh Fry also lists similar instances of the burial of the head and body in different locations, such as the burial of Murchad Ua Briain, whose head is said in the Annals of the Four Masters to have gone to Clonmacnoise and his body to Derry, and that of Hugh de Lacy, whose head and body were buried at different foundations, although as

74 HeIST 1965: 150, §15.

75 This passage from the Vita S. Fintani has been cited by Máire Herbert in connection with ideas concerning burial ad sanctos (HERBERT 2010: 252-3).

76 The Annals of Tigernach (s.a. 563), the Chronicon Scotorum (s.a. 565), the Annals of the Four Masters (s.a. 558) and the Annals of Clonmacnoise provide the same information in this regard, and the origin of the story is thus clearly to be found in Clonmacnoise (cf. CHARLES-EdwARDS 2000: 527: 'The monks of Clonmacnois later claimed that, while Díarmait's body was buried at Connor [...], his head was brought back and buried at their cemetery'). I cite the Chronicon Scotorum entry: tuccadh a cend co Cluáin muc Nois co ro adnacht innte, ocus ro hadhnacht a Colaind hi Condér, 'his head was brought to Cluain-muc-Nois, and interred therein; and his body was buried in Conner', (Hennessy 1866: 56-7). Susan Leigh Fry refers to the entries in the Annals of the Four Masters and the Annals of Clonmacnoise (FrY 1999: 99-100). Charles-Edwards has stated that the content of these particular entries probably dates to the tenth century (CHARLEs-Edwards 2000: 527, n.21: 'much of what is in the Clonmacnois group (AT [= Annals of Tigernach] and CS [= Chronicon Scotorum]) annal for 565 is likely to be of tenth-century date'), and Rekdal has discussed the information regarding the separate burial of Díarmait's head and body in a little more detail (REKDAL 2011: 260-1). 
in the case of Díarmait, the head is not explicitly stated to be the main part of the body in any of these examples. ${ }^{77}$ In descriptions of Brian Boroma's burial, the heads of Conaing and Mothla are said to have been buried with Brian. ${ }^{78}$

While it is impossible to say whether salvation and resurrection were questions with which the author of the poem Inna hinada was concerned, ${ }^{79}$ it is possible that the focus in the poem on the heads of the Ulster heroes may reflect the belief that the site of the head's burial determined a person's burial place. It would, therefore, reflect medieval thinking on the hierarchy of the body and the relative weight of different burial locations. In focusing on the head, the poet ensures that the burial place he names is the most significant one. One can only speculate as to why this would have been important. It may be that in the light of varying traditions such an emphasis was designed as a guarantee for the veracity of the information contained in the poem. The accounts of Conchobar's death are a good illustration of the variety of traditions that could exist concerning an individual's burial place, and it may be that divergence in accounts is also found in connection with Cú Chulainn's death. According to Brislech Mór Maige Muirthemni, Cú Chulainn's head and arm were buried at Tara, ${ }^{80}$ and the poem Temair toga na tulach, edited by Gwynn as Temair III, ${ }^{81}$ also states that Cú Chulainn's head was buried at Tara:

\section{Corus Cind Chonchulainn chrúaid \\ ó Ráith Chonchobair sair-thúaid}

'The Measure of the Head of grim Cuchullin

lies north-east from Rath Conchobair'. ${ }^{82}$

77 Fry 1999: 100-1. Fry also places a number of instances in which a dead person's head is stolen and/or buried separately from the body within the context of ideas concerning a person's resurrection, the aim of the separation apparently being to prevent resurrection (Fry 1999: 96-9). However, while Fry takes account of the Christian dimension and fears concerning resurrection, she also appears to interpret the story from the Fragmentary Annals and the other passages she cites as indicating 'that the Celtic cult of the head was still being practised in Ireland in the Middle Ages and later' (FrY 1999: 97). Given the focus on the head elsewhere in medieval Europe, it seems very unlikely that these stories reflect any such cult; the aspect of shaming the opponent (as also suggested by FrY 1999: 99) and possible worries regarding resurrection seem to me to be much more relevant.

${ }^{78}$ For a consideration of the reasons for burying Conaing and Mothla with Brian, see CASEy 2010: 40-43.

${ }^{79}$ While Conchobar is credited with belief in the Christian God, I am not aware of any such tradition connected to Blaí.

${ }^{80}$ Kimpton 2009: 24. Kimpton considers the Book of Leinster text to be 'a late ninthor early tenth-century reworking of an early eighth-century composition' (KIMPTON 2009: 9).

81 GWYNN 1903-35: vol. I, 14-27.

82 Gwynn 1903-35: vol. I, 16-17, 11. 49-50. Gwynn refers to the corresponding prose dindshenchas passage in his notes on the text (GWYNN 1903-35: vol. I, 63); the prose 
According to the Early Modern Aided Con Culainn, however, Cú Chulainn's head was returned to Emer in Dundalk and reunited with Cú Chulainn's body after the head had initially been taken to Tara. ${ }^{83}$

With regard to Inna hinada, whatever the specific motivation for focusing on the location of the heads' burial in this instance, it is clear that the poem fits into the more general interest in burial that is displayed in early medieval Irish literature. The poem Fíanna bátar $i$ EEmain has been cited above, and there are dindshenchas poems such as Án-sin a maig mic ind Óc, attributed to Cináed úa hArtacáin, ${ }^{84}$ or Temair toga na tulach, ${ }^{85}$ which also list burial places. Other poems on the same subject include the poem 'On the graves of Leinster men'86 and the perhaps thirteenth-century poem on the graves of kings at Clonmacnoise. ${ }^{87}$ In our earliest surviving largely vernacular manuscript, Lebor na hUidre, one finds the prose text Senchas na relec, referred to above, which in this version includes Án sin a maig Meic ind Óc. ${ }^{88}$ Furthermore, the manuscript includes narrative texts in which supposedly secular figures and their burials are endowed with religious motifs and concerns. Thus, Fástini Airt meic Cuind is concerned with Art mac Cuind's burial place at the future site of the ecclesiastical foundation Treóit, and interest in the location of burial places may be discerned in Cath Cairn Chonaill, in which Díarmait promises his burial at Clonmacnoise $^{89}$ and Gúaire Aidne's dead body works a miracle as he is being buried..$^{90}$ Similarly, in the text Aided Echach maic Maireda the site of Lí Ban's ${ }^{91}$ grave is a matter of dispute, and once this is settled, her grave is described as a

reads Rath Concobair mic Nesa hi taeb in Tredumi 7 atúaidh 7 a dorus soir a comardus Corus a cind 7 meide Conculainn, 'The Fort of Conchobar Mac Nessa beside the Triple Mound with its door in the east, near the Adjustment of Cúchulainn's Head and Neck'; STOKEs 1894: 283 (text) and 287 (translation), §30.

83 VAN HAMEL 1933: 123.

${ }^{84}$ Gwynn 1903-35: vol. II, 10-17. As the title is quoted from Gwynn, it has not been normalised.

85 Gwynn 1903-35: vol. I, 14-27.

86 This is the modern title given to the poem beginning Lecht Cormaic meic Culennain in the edition in DoBbs 1953-54.

87 BEST 1905, from Rawlinson B 512. The poem is also edited and translated by Hennessy, from TCD MS 1291 (H.1.17), with identifications of the individuals listed in the poem in STOKEs 1872: vol. I, 79-81, where the argument is made that the poem must have been composed before 1224, due to the reference to Cathal Crobderg in the final stanza (STOKEs 1872: vol. I, 79).

${ }^{88}$ LU, 11. 4117-4204. The only other manuscript to contain Senchas na relec, the fifteenthcentury manuscript Trinity College Dublin MS 1336 (H.3.17), does not contain the poem.

${ }^{89} L U$, 11. 9599-600.

90 LU, 11. 9725-9.

91 See De VRIes 2012: 24-9 for arguments that the name should be spelt Lí Bán. The arguments in IMHOFF 2008: 126-7 suggest that the spelling Li Ban may also be appropriate. The decision must be based on interpretation and comparative arguments, as provided by DE VRIES, as neither manuscript spelling nor metrics provide an indica- 
site of miracles. ${ }^{92}$ The burial of these figures, who are not technically saints but to whom saintly characteristics are attributed, illustrates the wide significance of this theme. It was not restricted to either the political or the religious sphere, if this division can even be made, and one can easily find parallels between ideas and traditions concerning royal figures and those concerning saints. Thus, the concern with the location of burial places is common to both groups. The list of such early medieval Irish texts given above could doubtless be extended. The focus on burial in a society in which the grave played a significant role both from a religious point of view as well as from a secular point of view should come as no surprise. ${ }^{93}$

It is into this context that Inna hinada fits best. As far as can be argued on the basis of the three surviving stanzas, the poem appears to have shared with other poetry and prose sources a concern with burial places. The specific focus on the head is very likely to reflect ideas held more widely in Europe from classical antiquity into the high Middle Ages and beyond, and one might speculate that the emphasis on heads indicates a desire to lend authority to the information conveyed in the poem, a suggestion which appears all the more plausible if the location of burial places was an element of traditional learning concerning which competing traditions existed.

\section{Bibliographie}

Anderson, Alan Orr, \& Marjorie Ogilvie Anderson (ed.), 1961: Adomnán's Life of Columba. London, Edinburgh et al: Thomas Nelson and Sons (revised and reprinted Oxford: Clarendon Press, 1991).

BARney, Stephen A., et al. (ed.), 2006: The Etymologies of Isidore of Seville. Cambridge: Cambridge University Press.

Best, Richard Irvine (ed.), 1905: 'The graves of the kings at Clonmacnois', Ériu 2, 163-171.

Best, Richard Irvine (ed.), 1908-1910: 'The settling of the manor of Tara', Ériu 4, 121-172.

tion of the length of the vowel. As the question does not affect the arguments made here, I have used the predominant manuscript spelling ( $L i$ Ban), normalised to Lí Ban.

92 Do-gniter dano ferta 7 mirmaili trethi-si and sin, 'Wonders and miracles are done through her there', DE VRIEs 2012: 218-19.

93 See, for example, the discussion of Oenach Tailten by Catherine Swift, who notes the connection between the sites of oenaig and burial places (SwIFT 2000: 116 and references to primary sources in n. 34). Ellen Ettlinger also listed a number of sites which served as assembly and fair sites and which also featured burials (ETTLINGER 1952-4). For a similar possible connection between burial and assembly sites in Anglo-Saxon England, see Williams 2004. Furthermore, see Charles-Edwards's discussion of a pre-Christian connection between graves and boundaries (CHARLES-EDWARDS 1976). Elizabeth Fitzpatrick has analysed the connection between medieval royal inauguration and mounds, sometimes situated in a burial landscape and pre-historic in origin (see, for example, FitzPatrick 2004). 
BEST, Richard Irvine, 1912: 'Notes on the script of Lebor na hUidre', Ériu 6, 161-174. Bischoff, Bernhard, 1966: 'Die europäische Verbreitung der Werke Isidors von Sevilla', in: Bernhard Bischoff, Mittelalterliche Studien. Ausgewählte Aufsätze zur Schriftkunde und Literaturgeschichte. 3 vols. Stuttgart: Hiersemann. Vol. I, 171-194.

Breatnach, Caoimhín, 1996: ,Review of James Patrick Mallory \& Gerard StockMAN (ed.): Ulidia. Proceedings of the first international conference on the Ulster Cycle of tales. Belfast: December, 1994', Éigse 29, 200-208.

Breatnach, Liam, 1994: 'An Mheán-Ghaeilge', in: Kim McCone, Damian McManus, Cathal Ó Háinle, Nicholas Williams \& Liam Breatnach (ed.): Stair na Gaeilge in ómós do P[h]ádraig ÓFiannachta. Maigh Nuad: Roinn na SeanGhaeilge, Coláiste Phádraig, 221-333.

Breatnach, Liam, 2015: 'Sluindfet dúib dagaisti in dána: a Middle Irish poem on metres', in: Caoimhín Breatnach \& Meidhbhín Ní ÚrdaIl (ed.): Aon don éigse. Essays marking Osborn Bergin's centenary lecture on bardic poetry (1912). Dublin: Dublin Iinstitute for Advanced Studies, 51-90.

Brown, Elizabeth A.R., 1981: 'Death and the human body in the later Middle Ages: the legislation of Boniface VIII on the division of the corpse', Viator 12, 221-270.

Brown, Elizabeth A.R., 1990: 'Authority, the family, and the dead in late medieval France', French Historical Studies 61/4, 803-832.

Byrne, Francis John, 2001: Irish kings and high-kings. Second edition. Dublin: Four Courts Press.

CAREy, John, 1993: 'Review of Sharpe, Medieval Irish saints' Lives: an introduction to the Vitae sanctorum Hiberniae', Speculum 68, 260-262.

CArley, James P., \& Ann Dooley, 1991: 'An early Irish fragment of Isidore of Seville's Etymologiae', in: Lesley Abrams \& James P. CARLEY (ed.): The archaeology and history of Glastonbury Abbey. Essays in honour of the ninetieth birthday of C.A. Ralegh Radford. Woodbridge: Boydell Press, 135-62.

CARney, James, 1955: Studies in Irish literature and history. Dublin: Dublin Institute for Advanced Studies.

CASEY, Denis, 2010: 'Historical and literary representations of Brian Boru's burial in Armagh, 1014 AD', North Munster antiquarian journal 50, 29-44.

Charles-Edwards, Thomas M., 1976: 'Boundaries in Irish law', in: Peter Hayes SAwyer (ed.): Medieval settlement. Continuity and change. New York: Cranc, Russak \& Company, 83-87.

Charles-Edwards, Thomas M., 2000: Early Christian Ireland. Cambridge: Cambridge University Press.

CoHen, Esther, 2013: 'The meaning of the head in high medieval culture', in: SANTING, BAERT \& TRANINGER 2013: 59-76.

Collis, John, 2003: The Celts. Origins, myths \& inventions. Stroud: Tempus.

DE VRIES, Ranke (ed.), 2012: Two texts on Loch nEchach. De causis torchi Corc' Óche and Aided Echach maic Maireda. London: Irish Texts Society (vol. 65).

DobBs, Margaret E. (ed.), 1953-1954: 'On the graves of Leinster men', Zeitschrift für celtische Philologie 24, 139-153.

DouteIL, Herbert (ed.), 1976: Iohannnis Beleth summa de ecclesiasticis officiis (Corpus Christianorum Continuatio Mediaeualis 41-41A). Turnhout: Brepols. 
Duncan, Elizabeth, 2015: 'The palaeography of H in Lebor na hUidre', in: Ruairí Ó HUiginn (ed.): Lebor na hUidre (Codices Hibernenses eximii 1). Dublin: Royal Irish Academy, 29-52.

Du Plessis, Paul, 2010: Borkowski's textbook on Roman law. 4th ed. Oxford: Oxford University Press.

EichHorn-Mulligan, Amy, 2005: 'Togail Bruidne Da Derga and the politics of anatomy', CMCS 49 (Summer 2005), 1-19.

EtTlinger, Ellen, 1952-1954: 'The association of burials with popular assemblies, fairs and races in ancient Ireland', Études celtiques 6, 30-61.

Finucane, Ronald C., 1981: 'Sacred corpse, profane carrion. social ideals and death rituals in the later Middle Ages', in: Joachim WhALEy (ed.): Mirrors of mortality: Studies in the social history of death. London: Europa Publications, 40-60 (reprinted Abingdon: Routledge / New York: Routledge, 2011).

FItZPATRICK, Elizabeth, 2004: 'Royal inauguration mounds in medieval Ireland: antique landscape and tradition', in: Aliki Pantos \& Sarah Semple (ed.): Assembly places and practices in medieval Europe. Dublin: Four Courts Press, 44-72.

Fry, Susan Leigh, 1999: Burial in medieval Ireland, 900-1500. A review of the written sources. Dublin: Four Courts Press.

GOI: Rudolf Thurneysen, A grammar of Old Irish. Dublin: Dublin Institute for Advanced Studies, 1946 (revised and enlarged edition with supplement 1975).

Guyonvarc'H, Christian-J., 1958: 'Le meurtre de Conchobar', Ogam. Tradition celtique 10, 129-138.

Gwynn, Edward (ed.), 1903-1935: The metrical Dindsenchas (Todd lecture series 812). 5 vols. Dublin: Royal Irish Academy (reprinted Dublin: Dublin Institute for Advanced Studies, 1991).

Hallam, Elizabeth M., 1982: 'Royal burial and the cult of kingship in France and England, 1060-1330', fournal of medieval history 8, 359-380.

HeIst, William W. (ed.), 1965: Vitae sanctorum Hiberniae ex codice olim Salmanticensi nunc Bruxellensi. Brussels: Société des Bollandistes.

Hennessy, William M. (ed.), 1866: Chronicum Scotorum. A chronicle of Irish affairs, from the earliest times to A.D. 1135. London: Longmans, Green, Reader, and Dyer.

Herbert, Máire, 2001: 'Latin and vernacular hagiography of Ireland from the origins to the sixteenth century', in: Guy Philippart (ed.): Hagiographies 3. Turnhout: Brepols, 327-360.

Herbert, Máire, 2007: 'Crossing historical and literary boundaries: Irish written culture around the year 1000', CMCS 53/54, 2007, 87-101.

Herbert, Máire, 2010: 'Hagiography and holy bodies: observations on corporeal relics in pre-Viking Ireland', in: L'Irlanda e gli irlandesi nell'alto medioevo. Spoleto, 16-21 aprile 2009 (Settimane di studio della fondazione centro italiano di studi sull'alto medioevo LVII). Spoleto: Fondazione Centro italiano di studi sull'alto medioevo, 239-257.

Hillgarth, Jocelyn Nigel, 1984: 'Ireland and Spain in the seventh century', Peritia $3,1-16$.

Hogan, Edmund, 1910: Onomasticon Goedelicum locorum et tribuum Hiberniae et Scotiae. An index, with identifications, to the Gaelic names of places and tribes. 
Dublin: Hodges, Figgis \& Co / London: Williams \& Norgate (reprinted Dublin: Four Courts Press, 1993).

IмноF, Helen, 2008: 'The themes and structure of Aided Echach maic Maireda', Ériu $58,107-131$.

Iмноғғ, Helen, 2012: 'The different versions of Aided Chonchobair', Ériu 62, 43-99. ImHoff, Helen, 2013: 'The tradition of Art mac Cuind's burial at Treóit (Trevet, Co. Meath)', Ríocht na Midhe. Records of Meath Archaeological and Historical Society 24, 73-114.

Johnson, Máire, 2007: 'Preserving the body Christian: the motif of "recapitation" in Ireland's medieval hagiography', The heroic age. A journal of early medieval northwestern Europe 10; see <http://www.heroicage.org/issues/ 10/johnson.htmlhttp://www.heroicage.org/issues/10/johnson.html> [accessed 9 January 2014].

Keating = David Comyn \& Patrick S. DinneEn (ed.), Foras Feasa ar Éirinn le Seathrún Céitinn. The History of Ireland by Geoffrey Keating. London: Irish Texts Society (vols 4, 8, 9 and 15), 1902, 1905, 1908, 1913.

Kimpton, Bettina (ed.), 2009: The death of Cú Chulainn. A critical edition of the earliest version of Brislech mór Maige Muirthemni with introduction, translation, notes, bibliography and vocabulary (Maynooth medieval Irish texts VI). Maynooth: School of Celtic Studies, National University of Ireland, Maynooth.

Kobel, Chantal (ed.), 2014: A critical edition of Aided Chonchobair 'The violent death of Conchobar'; with translation, textual notes and bibliography. 2 vols. Unpublished PhD thesis, University of Dublin, Trinity College, Department of Irish and Celtic languages.

Le Goff, Jacques, 1989: 'Head or heart? The political use of body metaphors in the Middle Ages', in: Michel Feher with Ramona Naddaff \& Nadia Tazi (ed.): Fragments for a history of the human body. Part Three. New York: Zone, 13-26.

LiNDSAY, Wallace Martin (ed.), 1911: Isidori Hispalensis episcopi Etymologiarum sive originum libri $x x$ (Scriptorum classicorum bibliotheca Oxoniensis). 2 vols. Oxonii: e typographeo Clarendoniano.

$L L=$ Richard Irvine Best, Osborn BERgIn, Michael Alphonsus O'Brien \& Anne O'Sullivan (ed.): The Book of Leinster formerly Lebar na Núachongbála. 6 vols. Dublin: Dublin Institute for Advanced Studies, 1954, 1956, 1957, 1965, 1967, 1983. $L U=$ Richard Irvine BEST \& Osborn BERGIN (ed.): Lebor na Huidre. Book of the Dun Cow. Dublin: Royal Irish Academy, 1929 (reprinted with additional corrigenda 1953; reprinted Dublin: Dublin Institute for Advanced Studies, 1992).

MacAlister, Robert Alexander Stewart (ed.), 1938-1956: Lebor Gabála Érenn. The Book of the Taking of Ireland. 5 vols. Dublin / London: Irish Texts Society (vols. 34, 35, 39, 41, 44; vol. 34 reprinted 1993 with a new introduction by John CAREY). Mac EoIn, Gearóid, 1994: 'The interpolator H in Lebor na Huidre', in: James Patrick MALlory \& Gerard Stockman (ed.): Ulidia. Proceedings of the first international conference on the Ulster Cycle of tales. Belfast: December, 39-46.

MAIER, Bernhard, 2000: 'Comparing Fled Bricrenn with classical descriptions of continental Celts: parallels, problems and pitfalls', in: Pádraig Ó RIAIN (ed.): Fled Bricrenn. Reassessments (Irish Texts Society subsidiary series 10). Dublin: Irish Texts Society, 1-14. 
McCone, Kim, 1984: 'Aided Cheltchair maic Uthechair: Hounds, heroes and hospitallers in early Irish myth and story', Ériu 35, 1-30.

McCone, Kim, 1994: 'An tSean-Gheailge agus a réamhstair', in: Kim McCone, Damian McManus, Cathal Ó Háinle, Nicholas Williams \& Liam Breatnach (ed.): Stair na Gaeilge in ómós do P[h]ádraig Ó Fiannachta. Maigh Nuad: Roinn na Sean-Ghaeilge, Coláiste Phádraig, 61-219.

Meyer, Kuno (ed.), 1906: The death-tales of the Ulster heroes (Todd Lecture Series XIV). Dublin: Royal Irish Academy (reprinted Dublin: Dublin Institute for Advanced Studies, 1993).

Meyer, Kuno, 1909: A primer of Irish metrics. Dublin (School of Irish Learning): Hodges, Figgis, \& Co. / London: David Nutt.

Meyer, Kuno, 1921: 'Mitteilungen aus irischen Handschriften', Zeitschrift für celtische Philologie 13, 3-30.

Mommsen, Theodor, Paul Krueger \& Alan Watson (ed.), 1985: The Digest of fustinian. 4 vols. Philadelphia: University of Pennsylvania Press.

Murphy, Gerard, 1952: 'On the dates of two source used in Thurneysen's Heldensage', Ériu 16, 145-156.

MurPhy, Gerard, 1961: Early Irish metrics. Dublin: Royal Irish Academy.

Nic CÁRTHAIGH, Emma, 2007: 'Revenants and antediluvian lore in medieval Irish texts', in: Jason HARris \& Kathleen CAWSEy (ed.): Transmission and transformation in the Middle Ages. Texts and contexts. Dublin: Four Courts Press, 40-64.

Ó Concheanainn, Tomás, 1974: 'The reviser of Leabhar na hUidhre', Éigse 15.4, 277-288.

Ó Concheanainn, Tomás, 1984: 'LL and the date of the reviser of LU', Éigse 20, $212-225$.

O'CuRry, Eugene, 1861: Lectures on the manuscript materials of ancient Irish history. Dublin: James Duffy (reissue Dublin: William A. Hinch / Patrick Traynor, 1878; reprinted Dublin: Four Courts Press, 1995).

Ó RIAIn, Pádraig, 2011: A dictionary of Irish saints. Dublin: Four Courts Press.

Ó RIAIn, Pádraig, 2013: 'The O’Donohue Lives of the Salamancan codex: the earliest collection of Irish saints' Lives?', in: Sarah SheEhan, Joanne Findon \& Westley Follett (ed.): Gablánach in scélaigecht. Celtic studies in honour of Ann Dooley. Dublin: Four Courts Press, 38-52.

Oskamp, Hans Pieter Atze, 1966-1967: 'Notes on the history of Lebor na Huidre', Proceedings of the Royal Irish Academy 65 C, 117-137.

Osкамp, Hans Pieter Atze, 1975-1976: 'Mael Muire: compiler or reviser?', Éigse 16, 177-182.

Paravicini Bagliani, Agostino, 2001: 'The corpse in the Middle Ages: the problem of the division of the body', in: Peter Linehan \& Janet L. Nelson (ed.): The medieval world. London and New York: Routledge, 327-341.

REKDAL, Jan Erik, 2011: 'From wine in a goblet to milk in cowdung. The transformation of early Christian kings in three post-Viking tales from Ireland', in: Gro Steinsland, Jón Viðar SigurĐsson, Jan Erik Rekdal and Ian Beuermann (ed.): Ideology and power in the Viking and Middle Ages. Scandinavia, Iceland, Ireland, Orkney and the Faroes. Leiden: Brill, 211-267. 
Ross, Anne, 1967: Pagan Celtic Britain. Studies in iconography and tradition. London and New York: Routledge \& Kegan Paul / New York: Columbia University Press (revised edition London: Constable, 1992).

Ross, Anne, 1970: Everyday life of the pagan Celts. London: Batsford.

Santing, Catrien, Barbara Baert \& Anita Traninger (ed.), 2013: Disembodied heads in medieval and early modern culture (Intersections 28). Leiden: Brill.

SCHÄFER, Dietrich, 1920: 'Mittelalterlicher Brauch bei der Überführung von Leichen', Sitzungsberichte der preussischen Akademie der Wissenschaften, 478498.

Schmitz-Esser, Romedio, 2014: Der Leichnam im Mittelalter. Einbalsamierung, Verbrennung und die kulturelle Konstruktion des toten Körpers (MittelalterForschungen 48). Ostfildern: Jan Thorbecke Verlag.

Schrijver, Peter, 1997: Studies in the history of Celtic pronouns and particles (Maynooth Studies in Celtic Linguistics 2). Maynooth: Department of Old Irish, National University of Ireland, Maynooth.

ShARPE, Richard, 1991: Medieval Irish saints' Lives. An introduction to Vitae sanctorum Hiberniae. Oxford: Clarendon Press.

Sharpe, Richard, 1995: Adomnán of Iona. Life of St Columba. London: Penguin.

SHIRAI, Naoko, 1997: 'Traditions of beheading: a comparative study of Classical Irish and Anglo-Saxon cultures', in: Masahiko Kanno, Hiroshi Yamashita, Masatoshi KaWASAKI, Junko Asakawa, and Naoko Shirai (ed.): Medieval heritage. Essays in honour of Tadahiro Ikegami. Tokyo: Yushodo Press Co., 315-327.

Shogimen, Takashi, 2007: “'Head or heart?” revisited: physiology and political thought in the thirteenth and fourteenth centuries', History of political thought $28 / 2,208-229$.

SigurĐsson, Gísli, 1988: Gaelic influence in Iceland. Historical and literary contacts (Studia Islandica 46). Reykjavík: Bókaútgáfa Menningarsjóðs.

Sims-Williams, Patrick, 2006: 'Person-switching in Celtic panegyric: figure or fault?'. In Joseph Falaky NAGY \& Leslie Ellen Jones (ed.): Heroic poets and poetic heroes in Celtic tradition. A Festschrift for Patrick K. Ford (CSANA Yearbook 3-4). Dublin: Four Courts Press, 315-326.

Sims-Williams, Patrick, 2012: 'Celtic civilization: continuity or coincidence?', CMCS 64 (Winter 2012), 1-45.

SMYth, Marina, 1987: 'Isidore of Seville and early Irish cosmography', CMCS 14 (Winter 1987), 69-102.

SPERBER, Ingrid, 2004: “Late, and not of special distinction?" The misunderstood Life of St Fintan of Clonenagh', Ossory, Laois and Leinster 1, 28-49.

STOKES, Margaret (ed.), 1872: Christian inscriptions in the Irish language chiefly collected and drawn by George Petrie, LL. D. 3 vols. Dublin: Printed at the University Press for the Royal Historical and Archaeological Association of Ireland.

STOKEs, Whitley (ed.), 1894-1895: 'The prose tales in the Rennes dindsenchas', Revue celtique 15 (1894), 272-336, 418-484; 16 (1895), 1-83, 135-167, 269-312.

STOKEs, Whitley (ed.), 1902: 'On the deaths of some Irish heroes', Revue celtique 23, 303-348. 
STÜBER, Karin, 1998: The historical morphology of n-stems in Celtic (Maynooth studies in Celtic linguistics 3). Maynooth: Department of Old Irish, National University of Ireland, Maynooth.

SwifT, Catherine, 2000: 'Óenach Tailten, the Blackwater valley and the Uí Néill kings of Tara', in: Alfred P. SмYтн (ed.): Seanchas. Studies in early and medieval Irish archaeology, history and literature in honour of Francis 7 . Byrne. Dublin: Four Courts Press, 109-120.

SzÖvÉRFFY, Joseph, 1956: 'Heroic tales, medieval legends and an Irish story (literary background of a Donegal tale)', Zeitschrift für celtische Philologie 25, 183-210.

SzÖvÉRFFy, Josef, 1957: 'Die Herkunft einer Heldensage', in: J. SzÖvÉRFFy, Irisches Erzählgut im Abendland. Studien zur vergleichenden Volkskunde und Mittelalterforschung. Berlin: Erich Schmidt, 86-96.

THACKer, Alan, 1995: 'Membra disjecta: the division of the body and the diffusion of the cult', in: Clare StAncliffe \& Eric CAmbridge (ed.): Oswald. Northumbrian king to European saint. Stamford: Paul Watkins Publishing, 97-127.

Thurneysen, Rudolf (ed.), 1935: Scéla mucce meic Dathó (Mediaeval and Modern Irish series 6). Dublin: Dublin Institute for Advanced Studies.

Tracy, Larissa, \& Jeff MASSEy (ed.), 2012: Heads will roll. Decapitation in the medieval and early modern imagination (Medieval and Renaissance authors and texts 7). Leiden: Brill.

UhLICH, Jürgen, 2006: 'Some textual problems in Rónán’s lament I: two quatrains concerning Echaid’s daughter (Fingal Rónáin lines 180-7)’, Ériu 56, 13-62.

van Hamel, Anton Gerard (ed.), 1933: Compert Con Culainn and other stories (Mediaeval and Modern Irish series 3). Dublin: Dublin Institute for Advanced Studies.

Walker Bynum, Caroline, 1995: The resurrection of the body in western Christianity (Lectures on the history of religions sponsored by the American Council of Learned Societies. New Series 15). New York: Columbia University Press.

Warntjes, Immo, 2012: 'Programmatic double burial (body and heart) of the European high nobility, c. 1200-1400. Its origin, geography, and functions', in: Karl-Heinz SpIEß \& Immo Warntjes (ed.): Death at court. Wiesbaden: Harrassowitz, 197-259.

WAsserschleben, Hermann (ed.), 1885: Die irische Kanonensammlung. 2. Auflage. Leipzig: Tauchnitz (reprinted Aalen: Scientia, 1966).

WebB, Heather, 2010: The medieval heart. Yale: Yale University Press.

Williams, Howard, 2004: 'Assembling the dead', in: Aliki Pantos \& Sarah Semple (ed.): Assembly places and practices in medieval Europe. Dublin: Four Courts Press, 109-134.

Hann. Münden

Helen IMHOFF

helen.imhoff@gmail.com 